PERM JOURNAL OF PETROLEUM AND MINING ENGINEERING ВЕСТНИК ПНИПУ. ГЕОЛОГИЯ. НЕФТЕГАЗОВОЕ И ГОРНОЕ ДЕЛО ISSN 2224-9923 Volume / Toм 19 №2 2019 http://vestnik.pstu.ru/geo/

UDC 622.276:552.578.2.061.4

Article / Статья

(C) PNRPU / ПНИПУ, 2019

\title{
STUDY OF SECONDARY ALTERATIONS OF VISEAN RESEVOIR ROCKS OF SOLIKAMSK DEPRESSION IN CONDITION OF STABILIZATION OF ANCIENT OIL-WATER CONTACTS
}

\section{Sergey V. Galkin, Igor Yu. Kolychev, Denis V. Potekhin ${ }^{1}$, Pavel Yu. Ilyushin ${ }^{2}$}

Perm National Research Polytechnic University (29 Komsomolskiy av., Perm, 614990, Russian Federation)

${ }^{1}$ PermNIPIneft branch of LUKOIL-Engineering LLC in Perm (29 Sovetskoy Armii st., Perm, 614066, Russian Federation)

${ }^{2}$ SIE "PrognozRNM" LLC (21 Akademika Koroleva st., Perm, 614013, Russian Federation)

\section{ИЗУЧЕНИЕ ВТОРИЧНЫХ ИЗМЕНЕНИЙ ВИЗЕЙСКИХ КОЛЛЕКТОРОВ СОЛИКАМСКОЙ ДЕПРЕССИИ В УСЛОВИЯХ СТАБИЛИЗАЦИИ ДРЕВНИХ ВОДОНЕФТЯНЫХ КОНТАКТОВ}

\section{С.В. Галкин, И.Ю. Колычев, Д.В. Потехин ${ }^{1}$, П.Ю. Илюшин ${ }^{2}$}

Пермский национальный исследовательский политехнический университет (614990, Россия, г. Пермь, Комсомольский проспект, 29) Филиал ООО «ЛУКОЙЛ-Инжиниринг “ПермНИПИнефть”» (614066, Россия, г. Пермь, ул. Советской Армии, 29)

${ }^{2} \mathrm{OOO}$ «МИП “Прогноз РНМ”» (614013, Россия, г. Пермь, ул. Академика Королева, 21)

Received / Получена: 06.03.2019. Аccepted / Принята: 01.06.2019. Published / Опубликована: 28.06.2019

\section{Kevwords:}

bituminous sandstone. wettability, porosity. specific resistivity. hvdrophobic reservoir, ancient oilwater contact. X-rav core tomography. microscopic analysis of thin sections.
A model of multi-stage formation of Visean oil deposits in Solikamsk depression in condition of stabilization of ancient oil-

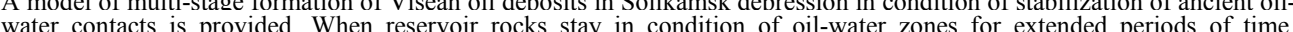
water contacts is provided. When reservoir rocks stav in condition of oil-water zones for extended periods of time. oxidizing processes actively develop. as result of which oil saturated reservoirs undergo non-reversible changes in rock oil oxidation are formed as solid bitumen. Cases of absence of reservoir bitumenosity in ranges of ancient oil-water contacts oil oxidation are formed as solid bitumen. Cases of are explained bv active fluid exchange in reservoirs

It is established that high specific resistance values in terrigenous reservoirs of Visean deposits in Solikamsk depression. exceeding $600 \mathrm{Ohm}^{*} \mathrm{~m}$. are related to their hydrophobization in conditions of ancient oil-water contacts. Electrical laterlog results are comnared with evaluation of rock wettabilitv based on X-rav core tomogranhv and microsconic analvsis of thin sections.

For Visean high-ohmic reservoirs of Shershnevskoe deposit statistically significant excess of rock porositv comparing to standard geophvsical section is established. For ranges with resistivity $<120 \mathrm{Ohm} * \mathrm{~m}$ porosity distribution maximum is observed within $12-16 \%$. In high-ohmic section for resistivity from 200 to $600 \mathrm{Ohm} * \mathrm{~m}$ maximal porositv freauencv is observed within $16-18 \%$ : for resistivity $>600 \mathrm{Ohm} * \mathrm{~m}$ - at porosity over $18 \%$. In average excess porosity in high-ohmic section is over $3 \%$. which is probablv due to pred

cementation at levels of ancient oil-water contacts. For Visean oberational obiects of Shershnevskoe deposit oir develonment. In general, the established zones of develonment of hydrophilic and hydrophobic reservoirs are of regular spatial arrangement. Geological models built with regard to rock wettability may be used to optimize reservoir management technologies at oil operational objects.

Предложена модель многоэтапного формирования визейских нефтяных залежей Соликамской депрессии в условиях стабилизации древних водонефтяных контактов. При длительном нахождении коллекторов в условиях условиях стабилизации древних водонефтяных контактов. При длительном нахождении коллекторов в условиях
водонефтяных зон происходит активное развитие окислительных процессов, в результате чего нефтенасыщенные водонефтяных зон происходит активное развитие окислительных процессов, в результате чего нефтенасыщенные
коллекторы подвергаются необратимым изменениям смачиваемости пород. После поступлений новых порций коллекторы подвергаются необратимым изменениям смачиваемости пород. После поступлений новых порций

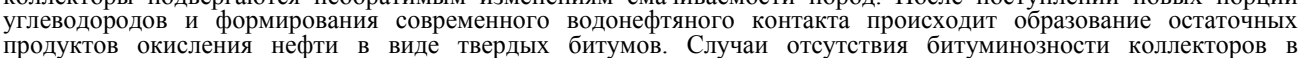
продуктов окисления нефти в виде твердых битумов. Случаи отсутствия битуминозности

Обосновано, что высокие удельные электрические сопротивления (УЭС) терригенных коллекторов визейских залежей Соликамской депрессии, превышающие 600 Ом'м, связаны с их гидрофобизацией в условиях древних водонефтяных контактов. Результаты электрического бокового каротажа сопоставлены с оценкой смачиваемости пород по данным рентгеновской томографии керна и микроскопическим анализом шлифов.

Для визейсии вия Для визейских высокоомных коллекторов Шершневского месторождения установлено статистически значимое превышение пористости пород в сравнении со стандартным геофизическим разрезом. Для интервалов с УЭС < 120 Ом·м наблюдается максимум распределения пористости в диапазоне от 12 до 16\%. В высокоомном разрезе для интервалов УЭС от 200 до 600 Ом·м наибольшая частота пористости установлена в диапазоне $16-18 \%$; для УЭС > 600 Ом·м - при пористости более $18 \%$. В среднем превышение пористости в высокоомном разрезе составляет более 3 \%, что, вероятно, является следствием преобладания на уровнях древних водонефтяных контактов процессов разуплотнения (растворения) коллекторов над их цементацией.

Для визейских эксплуатационных объектов Шершневского месторождения по данным значений УЭС построена геологическая модель с выделением зон (объемов) развития коллекторов различных типов смачиваемости. В целом установленные зоны развития гидрофильных и гидрофобных коллекторов имеют закономерное пространственное расположение. Геологические модели, построенные с учетом смачиваемости пород, могут быть использованы при оптимизации технологий разработки нефтяных эксплуатационных объектов.

Sergey V. Galkin (AuthorID in Scopus: 36711675500$)$ - Professor, Doctor of Geology and Mineralogy, Dean of the Mining and Oil Faculty. (mob. tel.: +007 902 631 20 13, e-mail: doc galkin $@$ mail.ru). The contact person for correspondence.

Igor Yu. Kolychev (AuthorID in Scopus: 56490995700) - Lead Engineer (mob. tel.: +007 90263120 13, e-mail: igorkolychev@gmail.com).

Denis V. Potekhin (AuthorID in Scopus: 56122662900) - PhD in Engineering, Head of the Department of Geological and Geophysical Modeling (mob. tel: +007902 6312013 , e-mail: Denis.Potekhin@pnn.lukoil.com).

Pavel Yu. Ilyushin (AuthorID in Scopus: 52563735500) - Associate Professor, PhD in Engineering, Director (mob. tel.: +007 9026312013 , e-mail: ilushin-pavel@yandex.ru).

Галкин Сергей Владиславович - профессор, доктор геолого-минералогических наук, декан горно-нефтяного факультета (тел.: +007902 631 2013 , e-mail: doc galkin $@$ mail.ru). Контактное лицо для переписки.

Колычев Игорь Юрьевич - ведущий инженер (тел.: +007 90263120 13, e-mail: igorkolychev@gmail.com).

Потехин Денис Владимирович - кандидат технических наук, начальник управления геолого-геофизического моделирования (тел.: +007902 6312013 , e-mail: Denis.Potekhin $@$ pnn.lukoil.com)

Илюшин Павел Юрьевич - доцент, кандидат технических наук, директор (тел.: +007 90263120 13, e-mail: ilushin-pavel@yandex.ru). 


\section{Introduction}

For a number of regions of Volga-Ural oil and gas province (OGP) (Bashkortostan, Tatarstan, etc.) multiple occurrences of bituminous sandstones are established [1-4]. In these cases rocks are naphtides (maltha, asphalts and asphaltites) practically not recoverable by modern methods. Presence of bitumen colors rocks in black, referred to in the literature as «black sandstones». Bitumenosity of «black sandstones» is commonly explained by oil oxidation at ancient oil-water contacts (OWC). Discovery of bituminous sandstones in terrigenous reservoirs at Pashian horizon of Romashkinskoe deposit as long as since 60-ies of XX century was explained by V. A. Retush (1965) as manifestation of traces of ancient OWC in section.

To the fullest extent process of ancient OWC influence is studied in works of R. S. Sakhibgareev $[1,5,6]$. According to his opinions, taken as basis for this work, two contrary processes - rock deconsolidation (dissolution) and cementation - take place at levels of OWC stabilization. Immediately at OWC place in general rock decomposition prevails, as dissolved components do not fully precipitate from bottom waters. As result, at place of ancient OWC formation of residual oil oxidation products in the form of solid bitumen is taking place.

Bituminous oil oxidation products may be extracted by the following portions of hydrocarbons, while this extraction takes place in selective manner. To the maximal degree bitumenosity signs are lost by the most permeable reservoirs, for which signs of initial bitumenosity are preserved in dead-end micro portions of pores. Less permeable rocks, to the contrary, contrast in geological section in the form of dark lenticular and striped compartments, due to preservation of bitumen.

Irregular bitumen extraction may result in layered bitumen pigmentation of rock in zones of ancient OWC, and in case of intense extraction in the whole geological section - lead to complete rock bleaching. Exactly such conditions, to opinion of the authors, prevail in case of Visean reservoirs in Solikamsk depression. For these producing facilities distribution of bituminous «black sandstones» with reservoir properties higher than cutoff values is not characteristic in general. At the same time for oilsaturated zones of Visean reservoirs abnormally high specific resistance values are noted, in number of cases exceeding 1000 Ohm*m. Reservoirs with abnormally high resistivity mainly are found within Solikamsk depression, though there are singular examples in other regions of Perm Territory. According to core data high-ohmic oil-saturated reservoirs are practically not distinguished in geological section, and usually are presented by light gray sandstones. Due to absence of evident signs of Visean reservoirs bitumenosity in Perm Territory, formation of such deposits have not been earlier viewed in relation to ancient OWC.

Works [7-9] give results of X-ray tomography core studies, showing that in conditions of abnormally high resistivity intervals rocks absolutely do not take water. This is regarded as consequence of manifestation of high hydrophobization of reservoirs [7-10]. According to modern views full hydrophobization of collectors is extremely rare and usually is characteristic for oil source rocks $[11,12]$. It is evident that Visean highly permeable layers could not be viewed as oil source rock. To the authors opinion, reservoir hydrophobization is residual consequence of deposit reformation at ancient OWC. Absence of bitumen in the reservoirs is related to active reservoir fluid exchange in results of several stages of hydrocarbons inflow.

As for Visean producing facilities of Solikamsk depression, according to modern views, at least two main stages of hydrocarbons input are presumed [13, 14]. First, in the end of late Carboniferous period, oil and gas source rock of Domanic age, being the main in the studied territory, came to main zone of oil and gas generation. As result, initial (ancient) OWC was formed, which existed for a long geological time. This has led to development of oxidation processes in water-oil transition zone reservoirs. Then in early Permian period (Asselian-Sakmarian age), along with intensive downwarping of Solikamsk depression, shale deposits of lower Carboniferous age, rich with organic substances, lowered to depths necessary to achieve sourcing potential. As result, new portion of hydrocarbons entered the deposit, forming OWC being close to the modern one. Implementation of this process was significantly aided by large amplitudes of local positive structures in Solikamsk depression, which provided for separation of secondary non-uniformities, related to stabilization of ancient $\mathrm{OWC}$, in conditions of multi-stage input of hydrocarbons into traps.

It is necessary to note that issue of studying ancient OWC in the given conditions is of not only great theoretical, but also practical importance. It is 
wettability factor which plays its especially great role in optimizing deposit development by water flooding [11, 15-17]. For Visean producing facilities in Solikamsk depression problem of insufficiently effective water flooding is especially pressing. For some areas reduction of intake capacity is observed already in first month of production, resulting in failure to reach design degree of oil withdrawal compensation by water flooding [18].

Except that, zones of hydrophilic and hydrophobic reservoirs significantly differ in oil production parameters, which determines its key role in determining methods to increase oil recovery [1922]. So, detailed elaboration of this issue shall permit (in relation to Visean producing facilities) to approach, in a more substantiated way, determination of optimal solutions during operation.

\section{Formation of deconsolidation and cementation zones in conditions of stabilization of ancient OWC}

An issue of influence of ancient OWC on the modern oil and gas occurrence was first brought about by G. I. Teodorovich (1944), who linked rock pyritization to sig of stabilization of OWC of Buguruslan deposit. O.A. Radchenko and V.A. Uspensky (1952) showed that oil in result of anaerobic oxidation may gradually transform to maltha and further to asphalt.

In zone of development of ancient OWC are established changes of feldspar in direction to processes of their caolinization [23] and especially pelitization [24]. Meanwhile high degree of feldspar change usually is accompanied by their pigmentation by bitumen substance. Analysis of pelitization coefficient [25] made in work [1] shows that for deposits in West Siberian oil and gas province maximum of pelitization is observed near to modern OWC. Significantly smaller changes are characteristic to sandstones both of edge water zone farthest from OWC and oil part unaffected by influence of OWC.

Main reason of intense rock alteration is formation of components aggressive to minerals in OWC stabilization zones. Many studies have established joined presence of sulfate-reducing and methane-producing microbial flora. Sulfate-draining microbial flora, by oxidizing organic substances and reducing sulfates, provides energy substrates $(\mathrm{CO} 2$, organic acids, etc.) for methane-forming bacteria.
Meanwhile, due to decreasing $\mathrm{pH}$ in aqueous media, favorable conditions for development of methaneproducing bacteria [1]. Except that, deposit bottom waters may have considerable aggressive potential, even though due to increased content of organic solvents, which, together with newly formed aggressive components, while oxidizing hydrocarbons at OWC, may dissolve minerals.

In conditions of bacterial methane production at OWC heavy oil thickening with precipitation of resinous-asphaltenic components may happen even without additional input of hydrocarbons. Meanwhile increase of deposit volume presumes increase of bitumen-containing substances, significantly leached due to participation of acid metabolic products of sulfate-reducing microorganisms.

At temperatures less than $100{ }^{\circ} \mathrm{C}$ two diverse processes may develop. On one side, minerals precipitation happens due to environment alkalization as result of consumption of organic acids and carbon dioxide by methane-producing microbial flora. Work [26] gives laboratory experimentations proving, for carbonate minerals, possibility of system equilibrium shift to calcite precipitation side during oxidation of organic substances. In situ this may lead to secondary calcite precipitation from dissolved waters with partial filling of reservoir voids. So, for number of deposits in Volga-Ural OGP examples of link between authigenic calcite and solid bitumen in border zone are established [27]. Examples of calcite cementation of terrigenous reservoirs in OWC zones are described by Yu. V. Schepetkin (1966, 1968, 1976), O. A. Chernikov (1969), V. F. Kozlov (1974).

In contrast with minerals precipitation they are dissolved due to excretion of acid metabolic products by sulfate-draining bacteria $(\mathrm{CO} 2$, organic acids, etc.). Work [28] gives examples of dissolution of anhydrite cement in conditions of activity of sulfatereducing bacteria for terrigenous reservoirs of deposits in Volga-Ural OGP in OWC zone. In such a way, both rock dissolution and cementation happen simultaneously in OWC area. Degree of manifestation of rock decomposition and cementation zones depends on character of OWC development.

As result of input of additional hydrocarbons volumes OWC shifts down section, which leads to capacitive reservoir growth (progressive type of OWC alteration). In this case not all dissolved minerals, and not to the full extent, precipitate in corresponding cementation zone. Very compact 
quartzitic sandstones happen to be impermeable by aggressive components, which penetrate into less silicified areas, and in case of intense fluid exchange turn them into highly capacitive loose varieties. Most demonstrably selective quartz cement dissolution manifests itself in bitumen-containing dissolution zone. Intensely silicified areas are distinguished by light color against background of dark grey or nearly black bitumen-containing varieties. Latter before deconsolidation differed from quartzitic varieties by somewhat greater porosity, which value increased due to dissolution by $1,2-2,0$ times.

At partial trap deforming OWC shifts up section (regressive type). In this case cementation processes explicitly prevail over dissolution. In general silicification processes in cementation zone are slowed by clay material, but at content of clay cement less than $5 \%$ inhibitory effect scarcely appear [1].

\section{Secondary reservoir alteration at ancient OWC in process of oil deposit formation}

In case of fast oil deposits formation minerals dissolution processes at ancient $\mathrm{OWC}$ are less expressed. The maximal oxidizing effect is observed in conditions of continuous and slow hydrocarbons input. Most aggressive environments, judging by secondary rock alterations, were created in conditions when not only sulfates and carbonates have been dissolving, but also quartz have been dissolving directly. In zones of stabilization of ancient OWC intense corrosion of various rockforming minerals is observed. Abundant signs of quartz grains corrosion are observed in zones containing solid bitumen.

Silica mobilized into solutions at ancient OWC, as a rule, is not moved beyond structure limits. In result of multistage deposit formation quartz redistribution is observed within traps, which is determined by water exchange troubles at ancient OWC. Formation of secondary varieties in this case happens at significant distance from fold of anticlinal trap due to deficit of input hydrocarbon.

The issue of secondary rock alterations at modern OWC in most details is studied by R. S. Sakhibgareev (1989) for terrigenous deposits of South Baltic. As result following vertical rock zones model in geological section is achieved.

To higher section part (above OWC) usually pertain cemented low-porous oil-saturated sandstones without signs of etching. For these rocks even in conditions of full quartz grains regeneration (5-8 \%) relatively high volume of capacitance space is preserved.

Lower, immediately in transition zone of OWC, rocks are being deconsolidated. In its upper part bitumen-containing sandstones rest, which due to uneven asphalt pigmentation obtain spotty dark gray and sometimes black color. Open porosity of bitumen sandstones comparing to oil-saturated varieties increases by 1,5 time, and permeability - by an order. Bitumen zone thickness is $2-3 \mathrm{~m}$, sometimes more, depending on conditions of downward spreading of aggressive products of oil oxidation and water exchange, providing for withdrawal of dissolved substances.

Below OWC surface follow light gray, almost loose water-saturated sandstones (thickness not exceeding $2 \mathrm{~m}$ ), by degree of quartz grains etching similar to bituminous sandstones. For deconsolidation zone reduction of regenerated quartz content to $1 \%$ is characteristic, silicification stays only at hardly permeable micro areas.

Lower than deconsolidation zone (going away from OWC transition zone) concentration of aggressive components in bottom waters reduces, and hard to dissolve components reach oversaturation phase. This leads to cementation and formation of compact quartzitic sandstones (thickness not exceeding $2 \mathrm{~m}$ ) with porosity less than $3 \%$. Contents of regenerated quartz in these may exceed $15 \%$, which practically excludes effective rock capacity. These sandstones, except for maximal input of silica, may differ by intense pyritization (isometric pyrite aggregates size up to $0,5 \mathrm{~mm}$ ).

Even lower down section degree of silicification reduces, and rocks by content of regenerated quartz come closer to same type of oil-saturated rocks. Parallel to reduction of sandstones silicification degree down section, signs of pyritization also disappear [1].

\section{Evaluation of reservoir wettability by core study and well logging}

Conclusions stated in the previous section are obtained on basis of analysis of modern OWC conditions. Diagnostics of ancient OWC is hindered by the fact that layers of bituminous sandstones, as a rule, does not lay strictly horizontally in geological section [29]. Except that, in high capacity bit 
relatively low-amplitude traps, due to merger of dissolution zones of several ancient OWC during multi-stage deposit formation, almost all oil-saturated medium may be involved, except for hardly permeable rock. To the greater extent analysis is complicated in case of partial bitumen extraction depending on reservoir permeability. So in study of ancient OWC complex analysis is necessary, based first of all on geophysical well logging and core material data.

Most informational in study of bituminous oil and respectively rock wettability in well logging is nuclear magnetic resonance logging (NMR) [30-36]. But in the Perm Territory intense reservoir bitumenosity is relatively rare. Due to this NMR studies are made in general on basis core only [37], and in wells are of a sporadic character.

In distinction from NMR electric methods are included into standard well logging complex, entirely describing geophysical section of all wells. Most credible in evaluation of resistance laterlog method is considered. Due to usage of guard electrodes for laterlogging reduction of influence is achieved, masking effects are reduced, permitting to study thin layers [38, 39]. Suitable for evaluation of layer resistance by laterlogging are data on well filled with aqueous mud having specific resistivity $g_{s}$ from 0,03 to $3 \mathrm{Ohm}^{*} \mathrm{~m}$.

During core studies it is necessary to combine data of standard studies (determination of porosity $K p$, water saturation $K w$, permeability $k$, etc.), special methods of wettability evaluation (X-ray core tomography, etc.) and microscopic analysis of thin sections. Complex analysis of these data with specific resistivity correlation to logging for Visean oil-saturated reservoirs is given in work [40]. Summarizing the results, it is possible to distinguish four types of oil-saturated reservoirs: highly porous hydrophobic; bituminous low porous with strong signs of hydrophobicity; with signs of hydrophobicity and hydrophilic.

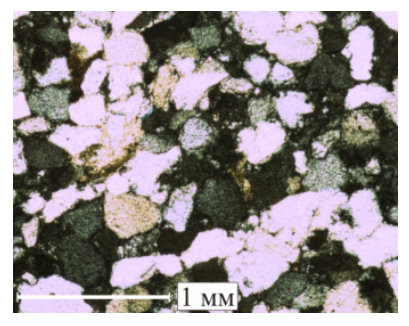

a

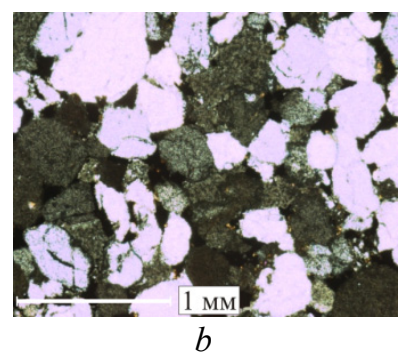

Core samples being hydrophobic according to tomography data are met within high-ohmic section with resistivity $>600 \mathrm{Ohm} * \mathrm{~m}$. Light samples without bitumenosity have $K p>20 \%$, and samples with bitumen cement $-K p$ within $11-13 \%$. Meanwhile permeability of light highly porous samples is by an order higher than that of bituminous samples. Samples with hydrophobicity signs are met in areas with resistivity from 120 to $600 \mathrm{Ohm}^{*} \mathrm{~m}$; for hydrophilic reservoirs resistivity $<100 \mathrm{Ohm} * \mathrm{~m}$ is characteristic [40].

For more detailed study of rocks the present work gives microscopic analysis of thin sections made from central part of the cores. Mineral composition of rocks and inclusions is studied on basis of thin sections, and also textural and structural features of the rocks. Photographs of thin sections for reservoirs with different wettability type are given in fig. 1 .

As shown above, one of associated signs of ancient OWC is rocks pyritization. Pyrite formation is related to activity of sulfate-reducing bacteria, due to interaction of iron-containing aqueous solutions with hydrogen sulfide, usually evolved as result of decomposition of organic remains. Pyritization is related to abundant water exchange, where iron precipitates from bottom waters.

Analysis of mineral composition of Visean reservoirs showed presence of pyrite in $75 \%$ thin sections made of hydrophilic core samples, having moderate (according to tomography data) hydrophobicity signs, while pyrite is absent in hydrophobic samples. This correlates well with data of R. S. Sakhibgareev (1989), according to which pyrite is instable in oxidation zone and in presence of free oxygen easily transforms to iron sulfate. The latter decomposes into insoluble ferrous hydroxide (limonite) and free sulfuric acid passing into solution. Except that absence of pyrite in bituminous media in dissolution zones may be related to formation of iron-organic complexes, which may show resistance to action of hydrogen sulfide [1].
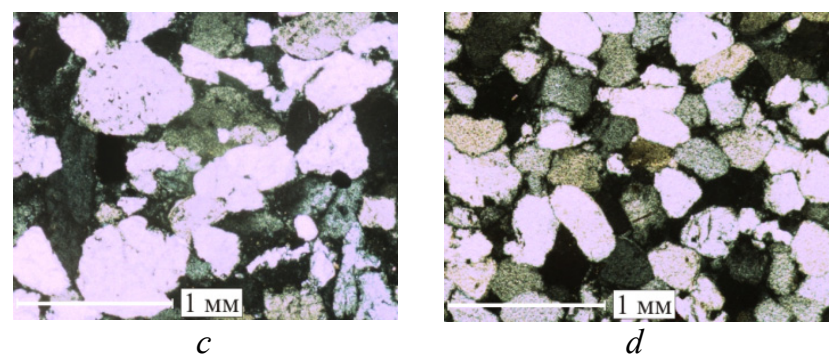

Fig. 1. Photographs of thin sections of core with crossed nicols: $a$ - hydrophobic sample (cylinder 84911); $b$ - bituminized sample with strong signs of hydrophobicity (cylinder 66541);

$c$-sample with signs of hydrophobicity (cylinder 101116); $d$-hydrophilic sample (cylinder 108484) 
Characterizing the studied thin sections, we may say that in general quartz grains are observed (from 69 to $89 \%$ ), other minerals are obviously subordinate. In theory redistribution of quartz should happen in process of multi-stage deposit formation by reduction of quartz concentration in zone of ancient OWC influence and sedimentation in edge water zones in direction of bottom waters flow. But here, though, it is possible to evaluate rather scales of quartz dissolution during deposit formation process, but not scales of its sedimentation beyond ancient OWC influence contour. That is why absence of significant differences in quartz content for studied reservoir types could not be viewed as a controversy. More important is that, according to thin section analysis data, quartz in cores with hydrophobicity signs has significantly more relief grain boundaries, which probably points to traces of its dissolution.

Incorporative contacts are characteristics for all thin sections from samples with hydrophobicity signs (see fig. 1, $a-c$ ), meanwhile specifically for hydrophobic highly porous sample (resistivity $=1800 \mathrm{Ohm} * \mathrm{~m}$ ) there observed most relief microstylolitic type of intergranular contacts (see fig. 1,a). It is necessary to note that for the most highly porous loose samples $(K p>20 \%)$ thin sections characterize the most compact core part. For example, $K p$ evaluation based on thin section (see fig. $1, a$ ) is mot more than $10 \%$; during evaluation of $K p$ at standard 30 millimeter core $K p=21,4 \%$. This permits to suppose even greater actual differences of this core type from the other types.

Significantly less porous $(K p=13,5 \%)$ and by an order less permeable $\left(k=0,055 \mathrm{um}^{2}\right)$ is hydrophobic sample (resistivity $=620 \quad \mathrm{Ohm}^{*} \mathrm{~m}$ ). Contents of clay bitumen aggregate in thin section is $10 \%$, next to quartz grains black clay bitumen pugs are observed (see fig. 1, b). At the same time, taking into account rather low density of solid bitumen, decompactification effect for this type of rocks to a great extent also continues. Difficult water exchange paths in thin section are determined in the form of small microstylolite contacts made in clay bitumen substance. Stylolite elements present in thin section probably reflect rock dissolution processes in paths of aggressive media filtration. It would be incorrect to view their formation in relation to migration of bitumen substance on them, as bitumens in stylolite seams are formed mainly by passive concentration similar to insoluble constituent of rock [1].

For hydrophilic samples in thin sections most characteristic are linear and conformal contacts, incorporative contacts are less common. Grains for hydrophilic samples are most rounded which may be regarded as sign of absence of minerals dissolution (see fig. 1, $d$ ). Except other, minimal contents of organic matters is established for hydrophilic samples.

So, microscopic analysis of thin sections demonstrated significant differences in core samples for various wettability types. Also, for all samples considered to be hydrophobic according to tomography data, signs of decompactification are established. Such signs become less evident with the reduction of hydrophobization degree and are least characteristic for hydrophilic samples. This conforms to theoretical concepts on secondary reservoir changes in conditions of ancient OWC.

\section{Allocation of secondary reservoir alterations at ancient OWC for Visean deposits of Shershnevskoe oil deposit}

As shown above, in case of progressive character of ancient OWC development reservoir decompactification processes prevail over their cementation. Then, accepting cause and effect relationship of abnormally high specific resistivity values and ancient OWC, capacity parameters in zones of abnormally high resistivity should be statistically different from standard conditions. First of all this should pertain to reservoir porosity $(K p)$. Let study this issue with the assistance of statistical data processing at the example of Visean producing facilities (layers $\mathrm{Tl}, \mathrm{Bb}, \mathrm{Ml}$ ) of Shershnevskoe oil deposit.

Distribution of average values $K p$

\begin{tabular}{|c|c|c|c|c|c|c|c|c|c|c|c|c|}
\hline \multirow{2}{*}{ Parameter } & \multicolumn{12}{|c|}{ Resistivity range, $\mathrm{Ohm} * \mathrm{~m}$} \\
\hline & $5-20$ & $20-50$ & $50-80$ & $80-120$ & $120-200$ & $200-300$ & $300-400$ & $400-500$ & $500-600$ & $600-700$ & $700-1000$ & $1000-2500$ \\
\hline$K p, \%$ & 14,0 & 14,0 & 15,0 & 14,7 & \multirow{2}{*}{ No data } & 16,0 & 16,1 & 17,0 & 16,5 & 17,5 & 18,2 & 17,5 \\
\hline$n$ & 15 & 34 & 36 & 22 & & 32 & 26 & 14 & 22 & 24 & 25 & 33 \\
\hline
\end{tabular}


The table shows distribution of average values of $K p$ according to logging data in various resistivity ranges. Analysis of table data permits to separate three ranges of rock resistivity values, for which $K p$ values are fundamentally different. First reservoir type in range of average values $K p$ from 14 to $15 \%$ is limited by resistivity values $<120 \quad \mathrm{Ohm}^{*} \mathrm{~m}$. Average value $K p$ and standard deviation for this type correspond to $14,5 \pm 2,8 \%$ at number of determinations $n=107$.

Starting from resistivity $>200 \mathrm{Ohm}^{*} \mathrm{~m}$, an abrupt increase of $K p$ values is noted, with their stabilization in resistivity range up to $600 \mathrm{Ohm} * \mathrm{~m}$. For this reservoir type $K p$ in average is notably higher: $16,3 \pm 2,2 \%$ at $n=94$. Next abrupt leap is observed at resistivity $>600 \mathrm{Ohm} * \mathrm{~m}$, without further growth at large resistivity values (see table). For high-ohmic reservoir type $K p=17,7 \%$ $\pm 2,3 \%$ at $n=82$.

To establish statistical differences of capacity parameters of reservoirs depending on resistivity statistical analysis of average values $K p$ of separated classes on Student's $t$-criterion was performed. As results it is established that acceptance of zero hypothesis is absolutely improbable. Probabilities of equality of means for classes correspondingly are: during comparison of low-ohmic reservoirs with intermediate class $0,0001 \%$, with high-ohmic classes - less than $0,00005 \%$, intermediate class with high-ohmic classes $-0,0033 \%$.

It is obvious that average values in classes do not fully characterize variety of geological settings in oil deposit. In conditions of stabilization of ancient OWC porosity should increase to the utmost extent in relatively high capacity and permeable intervals, and $K p$ values should grow less in less permeable areas. With regard to this $K p$ distribution histograms for separated classes are built (fig. 2).

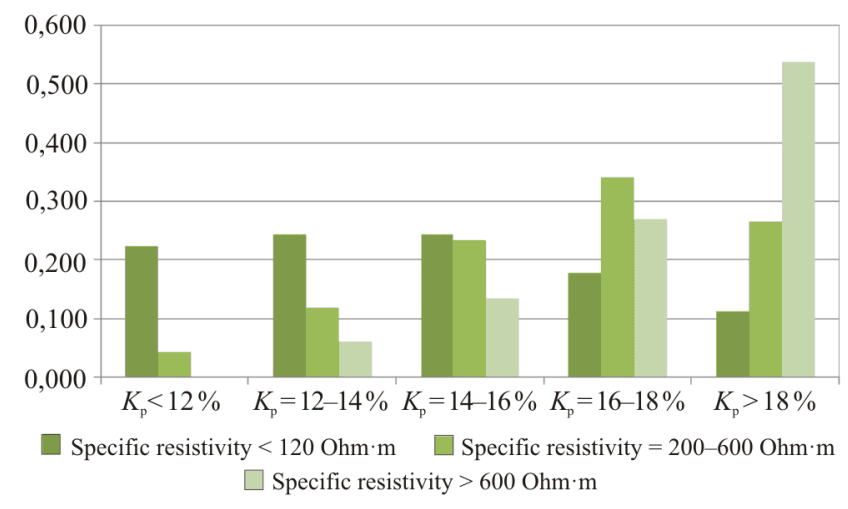

Fig. 2. Distribution of porosity coefficients depending on rock resistivity ranges for Shershnevskoe oil deposit

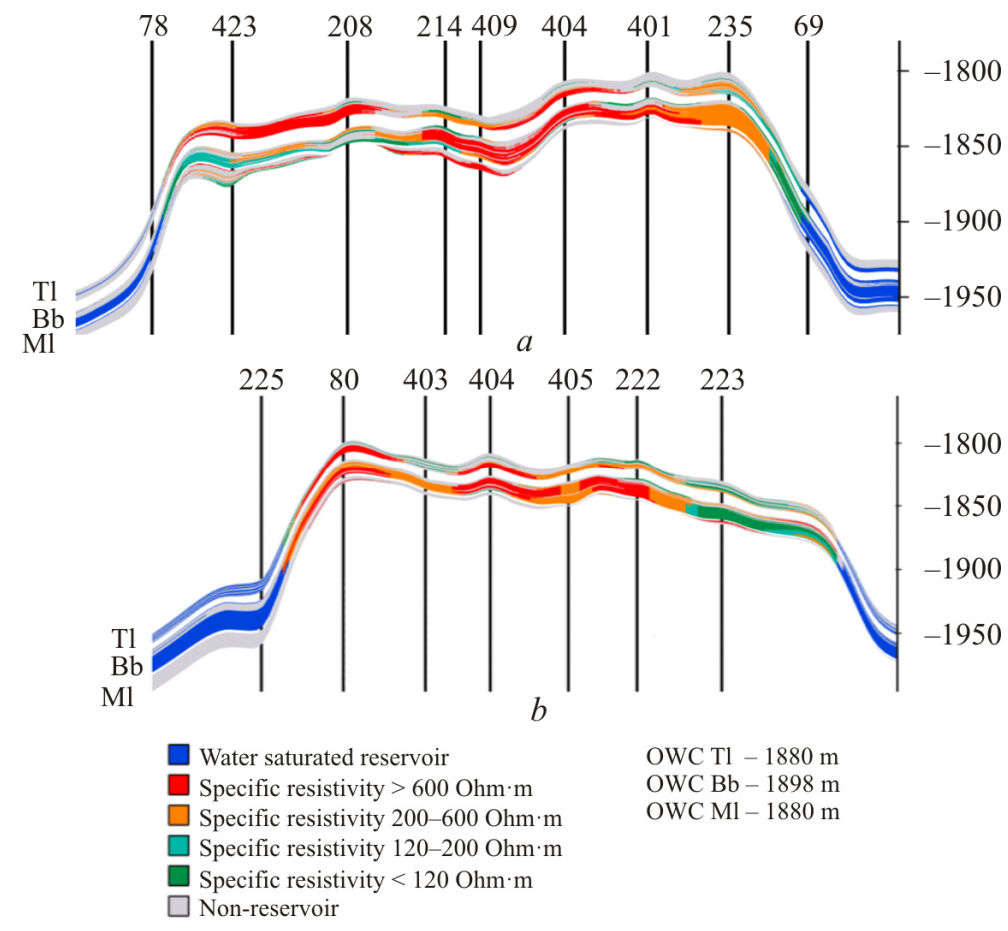

Fig. 3. Distribution of Visean reservoirs with various resistivity values in geological sections of Shershnevskoe oil deposit in directions south - north $(a)$; west - east $(b)$ 
From fig. 2 is clear that for intervals with resistivity $<120 \mathrm{Ohm} * \mathrm{~m}$, at generally uniform distribution of $K p$ maximum is observed in range from 12 to $16 \%$. In high-ohmic section for resistivity ranges from 200 to $600 \mathrm{Ohm}^{*} \mathrm{~m}$ maximal porosity frequency is established in range of $16-18 \%$, while reservoirs with $K p<12 \%$ are observed in less than 5 $\%$ of cases. For intervals with resistivity $>600$ Ohm*m reservoirs with $K p<12 \%$ are absent, and at $K p<14 \%$ their frequency is $6 \%$. Prominent maximum of frequency $K p(54 \%)$ for the most highohmic section is observed at $K p>18 \%$.

\section{Conclusions}

So, definitely significant statistical differences in rock porosity depending on specific resistivity are established. This, in the authors opinion, is direct consequence of reservoir decompactification processes in rock hydrophobicity zones, which in its turn is related to oxidation processes at ancient OWC. For Visean reservoirs of Shershnevskoe deposit average $K p$ value of low-ohmic section (14,5 $\%$ may be considered most typical for areas where OWC influence was minimal. Then an increase of $3,2 \%$ relative to it for high-ohmic reservoirs $(K p=$ $17,7 \%$ ) may be regarded as averaged increase due to decompactification in areas of ancient OWC.

At the final stage, for Visean reservoirs of Shershnevskoe deposit a geological model was built on basis of resistivity values, separating zones (volumes) of development of reservoirs with different wettability types (fig. 3). The model equates hydrophobic reservoirs with areas with resistivity $>$ $600 \mathrm{Ohm} * \mathrm{~m}$, and hydrophilic reservoirs - with areas with resistivity $<120 \mathrm{Ohm}^{*} \mathrm{~m}$.

The established zones of development of hydrophilic and hydrophobic reservoirs have regular spatial arrangement (see fig. 3). Development of hydrophilic reservoirs in general is associated with slope reservoir areas. In roof reservoir area predominantly spread are hydrophobic reservoirs, while in a number of cases immediately next to them zones of reservoir substitution with compact rocks (cementation areas) are adjacent, which is especially characteristic for Ml layer.

In general, issue of correlation of modern oil and gas content to ancient OWC for Visean reservoirs in Solikamsk depression seems to be a priority task related to improved development of the such. Geological models built with regard to rock wettability surely further detail geological setting of reservoirs. They may be useful in detailing reservoir capacity characteristics, and also may be used to optimize reservoir management technologies at oil operational objects.

\section{Acknowledgment}

The study sponsored by Perm Territory Administration. Agreement № S-26/174.7 (MIG-№ 28).

\section{References}

1. Sakhibgareev R.S. Vtorichnye izmeneniia kollektorov $\mathrm{V}$ protsesse formirovaniia i razrusheniia neftianykh zalezhei [Secondary reservoir changes in the process of formation and destruction of oil deposits]. Leningrad, Nedra, $1989,260 \mathrm{p}$

2. Mukhametshin R.Z. Rol i znachenie bituminoznykh peschanikov $\mathrm{V}$ produktivnykh plastakh [The role and importance of tar sands in reservoirs]. Prirodnye bitumy $i$ tiazhelye nefti. Mezhdunarodnaia nauchno-prakticheskaia konferentsiia $k$ stoletiiu prof. V.A. Uspenskogo. Ed. M.D. Belonin. Saint Petersburg, Nedra, 2006, pp.231-245.

3. Mukhametshin R.Z., Galeev A.A. Diagnostika drevnikh vodoneftianykh kontaktov instrumentalnymi metodami [Diagnostics of ancient oil-water contacts by instrumental methods]. Oil industry, 2014, no.10, pp.28-33.

4. Berezin V.M., Gizatullina V.V., Iarygina V.O. Nepodvizhnaia okislennaia neft $\mathrm{v}$ produktivnykh plastakh mestorozhdenii Bashkirii [Stationary oxidized oil in the productive strata of the fields of Bashkiria]. Trudy BashNIPIneft, 1983, iss.65, pp.43-52.

5. Sakhibgareev R.S. Etapnost formirovaniia i razrusheniia zalezhei po vtorichnym izmeneniiam kollektorov na drevnikh VNK [Staging of the formation and destruction of deposits of secondary reservoir changes in the ancient OWC]. Proiskhozhdenie $i$ prognozirovanie skoplenii gaza, nefti $i$ bitumov. Leningrad, Nedra, 1983, pp.130-143.

6. Sakhibgareev R.S. Izmenenie kollektorov na vodneftianykh kontaktakh [Change of collectors on oil- 
water contacts]. Doklady Akademii nauk SSSR, 1983, vol.271, no.6, pp.1456-1460.

7. Efimov A.A., Galkin S.V., Savitckii Ia.V., Galkin V.I. Estimation of heterogeneity of oil \& gas field carbonate reservoirs by means of computer simulation of core x-ray tomography data. Ecology, Environment and Conservation, 2015, vol.21, pp.79-85.

8. Efimov A.A., Savitckii Ia.V., Galkin S.V., Shapiro S. Experience of study of core from carbonate deposits by X-ray tomography. Perm Journal of Petroleum and Mining Engineering, 2016, vol.15, no.18, pp.23-32. DOI: 10.15593/2224-9923/2016.18.3

9. Efimov A.A., Savitskii Ia.V., Galkin S.V., Soboleva E.V., Gurbanov V.Sh. Issledovanie smachivaemosti kollektorov neftianykh mestorozhdenii metodom rentgenovskoi tomografii kerna [Study of wettability of reservoirs of oil fields by the method of X-ray tomography core]. Nauchnye trudy NIPI Neftegaz GNKAR, 2016, vol.4, no.4, pp.55-63. DOI: 10.5510/OGP20160400298

10. Kolychev I.Iu., Galkin S.V., Lekomtsev A.V. Issledovanie gidrofobizatsii terrigennykh kollektorov kompleksirovaniem metodov elektricheskogo karotazha i rentgenovskoi tomografii kerna [Investigation of hydrophobization of terrigenous reservoirs by the complexing of electrical logging and $\mathrm{x}$-ray tomography methods]. Dostizheniia, problemy $i$ perspektivy razvitiia neftegazovoi otrasli. Sbornik materialov mezhdunarodnoi nauchno-prakticheskoi konferentsii, 2018, vol.2, pp.68-72.

11. Abdalla V., Bakli D.S., Karnegi E., Edvards D., Kherold B., Fordem E., Graue A., Khabashi T., Seleznev N., Siner K., Khusein Kh., Montaron B., Ziauddin M. Osnovy smachivaemosti [Basics of wettability]. Neftegazovoe obozrenie, 2007, vol.19, no.2, pp.54-75.

12. Akhmetov R.T., Mukhametshin V.V., Andreev A.V. Interpretatsiia krivykh kapilliarnogo davleniia pri smeshannoi smachivaemosti [Interpretation of capillary pressure curves in case of mixed-wettability]. Geologiia, geofizika $i$ razrabotka neftianykh mestorozhdenii, 2017, no. 4, pp.37-40.

13. Krivoshchekov S.N., Kozlova I.A., Sannikov I.V. Otsenka perspektiv neftegazonosnosti zapadnoi chasti solikamskoi depressii na osnove geokhimicheskikh i geodinamicheskikh dannykh [Estimate of the petroleum potential of the western Solikamsk depression based on geochemical and geodynamic data]. Oil industry, 2014, no.6, pp.12-15.
14. Galkin V.I., Kozlova I.A., Nosov M.A., Krivoshchekov S.N. Reshenie regionalnykh zadach prognozirovaniia neftenosnosti po dannym geologogeokhimicheskogo analiza rasseiannogo organicheskogo veshchestva porod domanikovogo tipa [Solutions to regional problems of forecasting oil bearing according to geological and geochemical analysis of dispersed organic matter of Domanic type rocks]. Oil industry, 2015, no.1, pp.21-24.

15. Akhmetov R.T., Mukhametshin V.Sh. Modelirovanie protsessa nefteizvlecheniia $\mathrm{s}$ ispolzovaniem opyta razrabotki mestorozhdenii, nakhodiashchikhsia dlitelnoe vremia $\mathrm{v}$ ekspluatatsii [The definition of octane number confusion of different classes of hydrocarbons in the gasoline catalytic reforming]. Neftegazovoe delo, 2011, vol.9. no.4, pp.47-50.

16. Chumakov G.N., Zotikov V.I., Kolychev I.Iu., Galkin S.V. Analiz effektivnosti primeneniia tsiklicheskoi zakachki zhidkosti na mestorozhdeniiakh s razlichnymi geologo-tekhnologicheskimi usloviiami [Analysis of the effectiveness of cyclic fluid injection application in various geological and technological conditions of oil fields development]. Oil industry, 2014, no.9, pp.96-99.

17. Akhmetov R.T., Mukhametshin V.V. Vodouderzhivaiushchshaia sposobnost i smachivaemost produktivnykh plastov [Water-retaining power and wetability of productive formation]. Neftegazovoe delo, 2016, vol.14. no. 2, pp.34-37.

18. Soboleva E.V., Efimov A.A., Galkin S.V. Analiz geologo-geofizicheskikh kharakteristik terrigennykh kollektorov pri prognoze priemistosti skvazhin mestorozhdenii Solikamskoi depressii [The analysis of geological and geophysical characteristics of terrigenous reservoirs at the forecast injectability of wells of Solikamskaya depression]. Oil industry, 2014, no.6, pp.20-22.

19. Mikhailov N.N., Sechina L.S., Gurbatova I.P. Pokazateli smachivaemosti $\mathrm{V}$ poristoi srede $\mathrm{i}$ zavisimost mezhdu nimi [Indicators of wettability in a porous medium and the relationship between them]. Aktualnye problemy nefti $i$ gaza, 2011, no.1 (3), pp.10.

20. Xizhnyak G.P., Amirov A.M., Mosheva A.M., Melexin S.V., Chizhov D.B. Influence of wettability on oil displacement efficiency. Perm Journal of Petroleum and Mining Engineering, 2013, vol.12, no.6, pp.54-63. DOI: 10.15593/2224-9923/2013.6.6

21. Mikhailov N.N., Motorova K.A., Sechina L.S. Geologicheskie faktory smachivaemosti porod- 
kollektorov nefti i gaza [Geological factors of oil and gas reservoir rocks wettability]. Delovoi zhurnal Neftegas.ru, 2016, no.3, pp.80-90.

22. Mikhailov N.N., Gurbatova I.P., Motorova K.A., Sechina L.S. Novye predstavleniia o smachivaemosti kollektorov nefti i gaza [New representations of wettability of oil and gas reservoirs]. Oil industry, 2016, no.7, pp.80-85.

23. Perozio G.N. Vtorichnye izmeneniia mezozoiskikh otlozhenii tsentralnoi i iugovostochnoi chastei Zapadno-Sibirskoi nizmennosti [Secondary changes in the Mesozoic deposits of the central and southeastern parts of the West Siberian Lowland]. Postsedimentatsionnye preobrazovaniia osadochnykh porod Sibiri. Novosibirsk, Nauka, 1967, pp.5-89.

24. Iliasova E.N., Sakhibgareev R.S. Vliianie uslovii formirovaniia neftianykh zalezhei na stepen izmeneniia polevykh shpatov [The influence of the formation of oil deposits on the degree of change of feldspar]. Vliianie vtorichnykh izmenenii porod osadochnykh kompleksov na ikh neftegazonosnost. Leningrad, VNIGRI, 1982, pp.103-115.

25. Prozorovich G.E., Valiuzhanin Z.L. Regeratsiia kvartsa i pelitizatsiia polevykh shpatov $\mathrm{v}$ neftenosnykh i vodonosnykh peschanikov UstBalykskogo mestorozhdeniia nefti (Zapadnaia Sibir) [Regeneration of quartz and pelitization of feldspar in oil-bearing and aquifer sandstones of the Ust-Balyksky oil field (Western Siberia)]. Doklady Akademii nauk SSSR, 1966, vol.168, no.4, pp.893-895.

26. Germanov A.I., Borzenkov I.A., Iusupova I.F. Preobrazovanie karbonatnykh porod na uchastkakh razvitiia biogennykh sulfatreduktsii i metano-obrazovaniia [Conversion of carbonate rocks in areas of development of biogenic sulfate reduction and methane formation]. Izvestiia Akademii nauk SSSR, Seriia geologiia, 1981, no.5, pp.106-113.

27. Ashirov K.B. Tsementatsiia prikonturnogo sloia neftianykh zalezhei $\mathrm{V}$ karbonatnykh kollektorakh i vliianie ee na razrabotku [Cementation of the marginal layer of oil deposits in carbonate reservoirs and its influence on the development]. Trudy Giprvostokneft, 1959, iss.2, pp.163-174.

28. Chepikov K.R., Ermolova E.P., Orlova N.A. Epigennye mineraly kak pokazateli vremeni prikhoda nefti $\mathrm{v}$ peschanye promyshlennye kollektory [Epigenic minerals as indicators of the time of arrival of oil in industrial sandy reservoirs]. Doklady
Akademii nauk SSSR, 1959, vol.125, no.5, pp.1097-1099.

29. Mukhametshin R.Z., Punanova S.A. Prirodnye bitumy $\mathrm{v}$ otlozheniiakh paleozoia Tatarstana: sostav, svoistva i vozmozhnosti izvlecheniia [Natural bitumens in Paleozoic sediments of Tatarstan: composition, properties, and extraction capabilities]. Vysokoviazkie nefti $i$ prirodnye bitumy: problemy $i$ povyshenie effektivnosti razvedki $i$ razrabotki mestorozhdenii. Mezhdunarodnaia nauchno-prakticheskaia konferentsiia. Kazan, FEN, 2012, pp.95-99.

30. Eriksson S., Lasic S., Topgaard D. Isotropic diffusion weighting in PGSE NMR by magnetic angle spinning of q-vector. Journal of Magnetic Resonance, 2013, vol.226, pp.13-18. DOI: $10.1016 /$ j.jmr.2012.10.015

31. Lee J.H., Okuno Y., Cavagnero S. Sensitivity enhancement in solution NMR: Emerging ideas and new frontiers. Journal of Magnetic Resonance, 2014, vol.241, iss.1, pp.18-31. DOI: 10.1016/j.jmr.2014.01.005

32. Martin R.W., Kelly J.E., Collier K.A. Spatial reorientation experiments for NMR of solids and partially oriented liquids. Progress in Nuclear Magnetic Resonance Spectroscopy, 2015, vol.90-91, pp.92-122. DOI: 10.1016/j.pnmrs.2015.10.001

33. Haouas M., Taulelle F., Martineau Ch. Recent advances in application of 27Al NMR spectroscopy to material science. Progress in Nuclear Magnetic Resonanceu Spectroscopy, 2016, vol.94-95, pp.11-36. DOI: 10.1016/j.pnmrs.2016.01.003

34. Krivdin L.B. Calculation of $15 \mathrm{~N}$ NMR chemical shifts: Recent advances and perspectives. Progress in Nuclear Magnetic Resonance Spectroscopy, 2017, vol.102-103, pp.98-119. DOI: 10.1016/j.pnmrs.2017.08.001

35. Vugmeyster L., Ostrovsky D. Static solid state $2 \mathrm{H}$ NMR methods in studies of protein side chain dynamics. Progress in Nuclear Magnetic Resonance Spectroscopy, 2017, vol.101, pp.1-17. DOI: 10.1016/j.pnmrs.2017.02.001

36. Pileio G. Singlet NMR methodology in two spin - 1/2 systems. Progress in Nuclear Magnetic Resonance Spectroscopy, 2017, vol.98-99, pp.1-19. DOI: 10.1016/j.pnmrs.2016.11.002

37. Zlobin A.A., Iushkov I.R. Opredelenie smachivaemosti poverkhnosti porovykh kanalov neekstragirovannykh porod-kollektorov [Definition of pore samples surface wettability in non-extracting rockcollectors]. Geology, Geophysics and Development of Oil and Gas Fields, 2009, no.10, pp.29-32. 
38. Gubina A.I., Kostlivykh L.N., Zriachikh E.S., Shumilov A.V. Kompiuternaia interpretatsiia dannykh geofizicheskikh issledovanii skvazhin [Computer interpretation of geophysical well data]. Perm', Izdatel'stvo Permskogo natsional'nogo issledovatel'skogo politekhnicheskogo universiteta, 2016, 218 p.

39. Kostitsyn V.I., Khmelevskoi V.K. Geofizika [Geophysics]. Perm', Izdatel'stvo Permskogo natsional'nogo issledovatel'skogo politekhnicheskogo universiteta, 2018, $428 \mathrm{p}$.

40. Kolychev I.Iu. Izuchenie zonalnosti raspredeleniia pokazatelei smachivaemosti po dannym bokovogo karotazha dlia neftenasyshchshennykh vizeiskikh kollektorov solikamskoi depressii. Perm Journal of Petroleum and Mining Engineering, 2017, vol.16, no.4, pp.331-341. DOI: 10.15593/2224-9923/2017.4.4

\section{Библиографический список}

1. Сахибгареев Р.С. Вторичные изменения коллекторов в процессе формирования и разрушения нефтяных залежей. - Ленинград: Недра, 1989. - 260 c.

2. Мухаметшин Р.3. Роль и значение битуминозных песчаников в продуктивных пластах // Природные битумы и тяжелые нефти: международная научно-практическая конференция к столетию проф. В.А. Успенского / под. ред. М.Д. Белонина. - Санкт-Петербург: Недра, 2006. - С. 231-245.

3. Мухаметшин Р.3., Галеев А.А. Диагностика древних водонефтяных контактов инструментальными методами // Нефтяное хозяйство. - 2014. № 10. - С. 28-33.

4. Березин В.М., Гизатуллина В.В., Ярыгина В.О. Неподвижная окисленная нефть в продуктивных пластах месторождений Башкирии // Труды БашНИПИнефть. - 1983. - Вып. 65. - С. 43-52.

5. Сахибгареев Р.С. Этапность формирования и разрушения залежей по вторичным изменениям коллекторов на древних ВНК // Происхождение и прогнозирование скоплений газа, нефти и битумов. - Ленинград: Недра, 1983. - С. 130-143.

6. Сахибгареев Р.С. Изменение коллекторов на водонефтяных контактах // Доклады Академии наук СССР. - 1983. - Т. 271, № 6. - С. 1456-1460.

7. Estimation of heterogeneity of oil \& gas field carbonate reservoirs by means of computer simulation of core x-ray tomography data / A.A. Efimov, S.V. Galkin, Ia.V. Savitckii, V.I. Galkin // Ecology, Environment and Conservation. - 2015. - Vol. 21. P. 79-85.

8. Опыт исследования керна карбонатных отложений методом рентгеновской томографии / А.А. Ефимов, Я.В. Савицкий, С.В. Галкин, С.А. Шапиро // Вестник Пермского национального исследовательского политехнического университета. Геология. Нефтегазовое и горное дело. - 2016. - Т. 15, № 18. - С. 23-32. DOI: $10.15593 / 2224-9923 / 2016.18 .3$

9. Исследование смачиваемости коллекторов нефтяных месторождений методом рентгеновской томографии керна / А.А. Ефимов, Я.В. Савицкий, С.В. Галкин, Е.В. Соболева, В.Ш. Гурбанов // Научные труды НИПИ Нефтегаз ГНКАР. - 2016. T. 4, № 4. - C. 55-63. DOI: 10.5510/OGP20160400298

10. Колычев И.Ю., Галкин С.В., Лекомцев А.В. Исследование гидрофобизации терригенных коллекторов комплексированием методов электрического каротажа и рентгеновской томографии керна // Достижения, проблемы и перспективы развития нефтегазовой отрасли: сборник материалов международной научнопрактической конференции / Альметьевский государственный нефтяной институт. Альметьевск, 2018. - Т. 2. - С. 68-72.

11. Основы смачиваемости / В. Абдалла, Д.С. Бакли, Э. Карнеги, Д. Эдвардс, Б. Херольд, Э. Фордэм, А. Грауэ, Т. Хабаши, Н. Селезнев, К. Синьер, Х. Хусейн, Б. Монтарон, М. Зиауддин // Нефтегазовое обозрение. - 2007. - Т. 19, № 2. - С. 54-75.

12. Ахметов Р.Т., Мухаметшин В.В., Андреев А.В. Интерпретация кривых капиллярного давления при смешанной смачиваемости // Геология, геофизика и разработка нефтяных месторождений. - 2017. № 4. - C. 37-40.

13. Кривощеков С.Н., Козлова И.А., Санников И.В. Оценка перспектив нефтегазоносности западной части Соликамской депрессии на основе геохимических и геодинамических данных // Нефтяное хозяйство. -2014 . - № 6. - С. 12-15.

14. Решение региональных задач прогнозирования нефтеносности по данным геолого-геохимического анализа рассеянного органического вещества пород доманикового типа / В.И. Галкин, И.А. Козлова, М.А. Носов, С.Н. Кривощеков // Нефтяное хозяйство. - 2015. - № 1. - С. 21-24. 
15. Ахметов Р.Т., Мухаметшин В.Ш. Моделирование процесса нефтеизвлечения с использованием опыта разработки месторождений, находящихся длительное время в эксплуатации // Нефтегазовое дело. - 2011. - Т. 9, № 4. - С. 47-50.

16. Анализ эффективности применения циклической закачки жидкости на месторождениях с различными геолого-технологическими условиями / Г.Н. Чумаков, В.И. Зотиков, И.Ю. Колычев, С.В. Галкин // Нефтяное хозяйство. 2014. - № 9. - С. 96-99.

17. Ахметов Р.Т., Мухаметшин В.В. Водоудерживающшая способность и смачиваемость продуктивных пластов // Нефтегазовое дело. 2016. - T. 14, № 2. - С. 34-37.

18. Соболева Е.В., Ефимов А.А., Галкин С.В. Анализ геолого-геофизических характеристик терригенных коллекторов при прогнозе приемистости скважин месторождений Соликамской депрессии // Нефтяное хозяйство. - 2014. - № 6. C. 20-22.

19. Михайлов Н.Н., Сечина Л.С., Гурбатова И.П. Показатели смачиваемости в пористой среде и зависимость между ними // Актуальные проблемы нефти и газа. - 2011. - № 1 (3). - С. 10.

20. Влияние смачиваемости на коэффициент вытеснения нефти / Г.П. Хижняк, А.М. Амиров, А.М. Мошева, С.В. Мелехин, Д.Б. Чижов // Вестник Пермского национального исследовательского политехнического университета. Геология. Нефтегазовое и горное дело. - 2013. - Т. 12, № 6. C. 54-63. DOI: 10.15593/2224-9923/2013.6.6

21. Михайлов Н.Н., Моторова К.А., Сечина Л.С. Геологические факторы смачиваемости породколлекторов нефти и газа // Деловой журнал Neftegas.ru. - 2016. - № 3. - С. 80-90.

22. Новые представления о смачиваемости коллекторов нефти и газа / Н.Н. Михайлов, И.П. Гурбатова, К.А. Моторова, Л.С. Сечина // Нефтяное хозяйство. - 2016. - № 7. C. $80-85$.

23. Перозио Г.Н. Вторичные изменения мезозойских отложений центральной и юговосточной частей Западно-Сибирской низменности // Постседиментационные преобразования осадочных пород Сибири. - Новосибирск: Наука, 1967. - С. 5-89.

24. Ильясова Е.Н., Сахибгареев Р.С. Влияние условий формирования нефтяных залежей на степень изменения полевых шпатов // Влияние вторичных изменений пород осадочных комплексов на их нефтегазоносность. - Ленинград: ВНИГРИ, 1982. - C. 103-115.

25. Прозорович Г.Э., Валюжанин З.Л. Регерация кварца и пелитизация полевых шпатов и нефтеносных и водоносных песчаников Усть-Балыкского месторождения нефти (Западная Сибирь) // Доклады АН СССР. - 1966. - Т. 168, № 4. C. 893-895.

26. Германов А.И., Борзенков И.А., Юсупова И.Ф. Преобразование карбонатных пород на участках развития биогенных сульфатредукций и метанообразования // Известия Академии наук СССР. Серия: Геология, 1981. - № 5. C. 106-113.

27. Аширов К.Б. Цементация приконтурного слоя нефтяных залежей в карбонатных коллекторах и влияние ее на разработку // Труды Гипрвостокнефть. - 1959. - Вып. 2. - С. 163-174.

28. Чепиков К.Р., Ермолова Е.П., Орлова Н.А. Эпигенные минералы как показатели времени прихода нефти в песчаные промышленные коллекторы // Доклады Академии наук СССР. 1959. - Т. 125, № 5. - С. 1097-1099.

29. Мухаметшин Р.3., Пунанова C.A. Природные битумы в отложениях палеозоя Татарстана: состав, свойства и возможности извлечения // Высоковязкие нефти и природные битумы: проблемы и повышение эффективности разведки и разработки месторождений: международная научно-практическая конференция. - Казань: ФЭН, 2012. - C. 95-99.

30. Eriksson S., Lasic S., Topgaard D. Isotropic diffusion weighting in PGSE NMR by magnetic angle spinning of q-vector // Journal of Magnetic Resonance. - 2013. - Vol. 226. - P. 13-18. DOI: $10.1016 /$ j.jmr.2012.10.015

31. Lee J.H., Okuno Y., Cavagnero S. Sensitivity enhancement in solution NMR: Emerging ideas and new frontiers // Journal of Magnetic Resonance. 2014. - Vol. 241, iss. 1. - P. 18-31. DOI: $10.1016 /$ j.jmr.2014.01.005

32. Martin R.W., Kelly J.E., Collier K.A. Spatial reorientation experiments for NMR of solids and partially oriented liquids // Progress in Nuclear Magnetic Resonance Spectroscopy. - 2015. - Vol. 90-91. P. 92-122. DOI: 10.1016/j.pnmrs.2015.10.001

33. Haouas M., Taulelle F., Martineau Ch. Recent advances in application of 27Al NMR spectroscopy to material science // Progress in Nuclear Magnetic Resonance Spectroscopy. - 2016. Vol. 94-95.-P. 11-36. DOI: 10.1016/j.pnmrs.2016.01.003 
34. Krivdin L.B. Calculation of $15 \mathrm{~N}$ NMR chemical shifts: Recent advances and perspectives // Progress in Nuclear Magnetic Resonance Spectroscopy. - 2017. - Vol. 102-103. - P. 98-119. DOI: 10.1016/j.pnmrs.2017.08.001

35. Vugmeyster L., Ostrovsky D. Static solid state 2H NMR methods in studies of protein side chain dynamics // Progress in Nuclear Magnetic Resonance Spectroscopy. - 2017. - Vol. 101. P. 1-17. DOI: 10.1016/j.pnmrs.2017.02.001

36. Pileio G. Singlet NMR methodology in two spin - 1/2 systems // Progress in Nuclear Magnetic Resonance Spectroscopy. - 2017. - Vol. 98-99. - P. 1-19. DOI: 10.1016/j.pnmrs.2016.11.002

37. Злобин А.А., Юшков И.Р. Определение смачиваемости поверхности поровых каналов неэкстрагированных пород-коллекторов //
Геология, геофизика и разработка нефтяных и газовых месторождений. - 2009. - № 10. - С. 29-32.

38. Компьютерная интерпретация данных геофизических исследований скважин / А.И. Губина, Л.Н. Костливых, Е.С. Зрячих, А.В. Шумилов; Перм. гос. нац. исслед. ун-т. - Пермь, 2016. - 218 с.

39. Костицын В.И., Хмелевской В.К. Геофизика / Перм. гос. нац. исслед. ун-т. - Пермь, 2018. $-428 \mathrm{c}$.

40. Колычев И.Ю. Изучение зональности распределения показателей смачиваемости по данным бокового каротажа для нефтенасыщен-ных визейских коллекторов Соликамской депрессии // Вестник Пермского национального исследовательского политехнического университета. Геология. Нефтегазовое и горное дело. - 2017. - Т. 16, № 4. C. 331-341. DOI: 10.15593/2224-9923/2017.4.4

Please cite this article in English as:

Galkin S.V., Kolychev I.Yu., Potekhin D.V., Ilyushin P.Yu. Study of secondary alterations of visean resevoir rocks of Solikamsk Depression in condition of stabilization of ancient oil-water contacts. Perm Journal of Petroleum and Mining Engineering, 2019, vol.19, no.2, pp.104-116. DOI: 10.15593/2224-9923/2019.2.1

Просьба ссылаться на эту статью в русскоязычных источниках следующим образом:

Изучение вторичных изменений визейских коллекторов Соликамской депрессии в условиях стабилизации древних водонефтяных контактов / С.В. Галкин, И.Ю. Колычев, Д.В. Потехин, П.Ю. Илюшин // Вестник Пермского национального исследовательского политехнического университета. Геология. Нефтегазовое и горное дело. - 2019. T.19, №2. - C.104-116. DOI: 10.15593/2224-9923/2019.2.1 